\title{
Pension Privatization and Country Risk
}

\author{
Alfredo Cuevas, María Gonzalez, \\ Davide Lombardo and \\ Arnoldo López-Marmolejo
}





\title{
IMF Working Paper
}

\author{
Western Hemisphere Department
}

\section{Pension Privatization and Country Risk ${ }^{1}$}

\author{
Prepared by Alfredo Cuevas, María González, Davide Lombardo ${ }^{2}$ \\ and Arnoldo López-Marmolejo ${ }^{3}$
}

Authorized for distribution by Martin Mühleisen

August 2008

\begin{abstract}
This Working Paper should not be reported as representing the views of the IMF. The views expressed in this Working Paper are those of the author(s) and do not necessarily represent those of the IMF or IMF policy. Working Papers describe research in progress by the author(s) and are published to elicit comments and to further debate.

This paper explores how privatizing a pension system can affect sovereign credit risk. For this purpose, it analyzes the importance that rating agencies give to implicit pension debt (IPD) in their assessments of sovereign creditworthiness. We find that rating agencies generally do not seem to give much weight to IPD, focusing instead on explicit public debt. However, by channeling pension contributions away from the government and creating a deficit of resources to cover the current pension liabilities during the reform's transition period, a pension privatization reform may transform IPD into explicit public debt, adversely affecting a sovereign's perceived creditworthiness, thus increasing its risk premium. In this light, accompanying pension reform with efforts to offset its transition costs through fiscal adjustment would help preserve a country's credit rating.

JEL Classification Numbers: H55, F34

Keywords: Credit Risk, Credit Ratings, Pension Reform, Public Debt, Transition Costs Authors' E-Mail Addresses: acuevas@imf.org; mgonzalez@imf.org; dlombardo@imf.org; alopezm@banxico.org.mx

\footnotetext{
${ }^{1}$ We acknowledge helpful comments and suggestions from seminar participants at the Economic Panel of the Fiscal Affairs Department of the International Monetary Fund (and in particular of Todd Groome), as well as from Manuel Arellano and Hugo Rodriguez Mendizabal. We also thank Noel Perez Benitez for excellent research assistance.

${ }^{2}$ All from the International Monetary Fund

${ }^{3}$ Banco de México.
} 


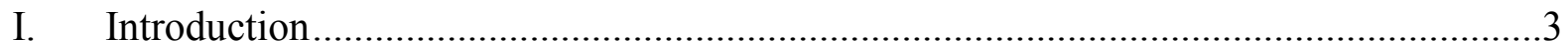

II. Country Risk, Credit Ratings and Implicit Pension Debt (IPD) ..................................5

III. Econometric Analysis .......................................................................................

IV. A Counterfactual Study: Mexico's Pension Reform ............................................. 14

A. Pension Privation in Mexico ............................................................................ 14

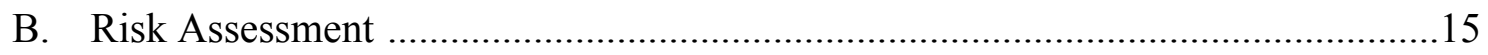

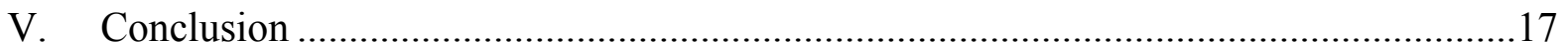

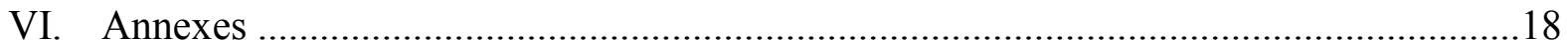

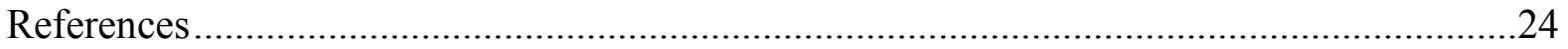

\section{Tables}

1. Institutional Investor Ratings (IIR), IPD and Debt ............................................

2. IIR and Pension Reform: Static Panel Estimation with Fixed Effects ..........................12

3. IIR and Pension Reform: Dynamic Panel (2SLS) Estimation Results .........................13

4. Estimated Impact of Pension Reform on IIR ..................................................... 16

\section{Figures}

1. Standard and Poor's Creidt Ratings and Government Debt .......................................6

2. Risk Premia and International Investor Ratings ......................................................6

3. Mexico: Counterfactual Explicit Debt and Primary Balance …................................15

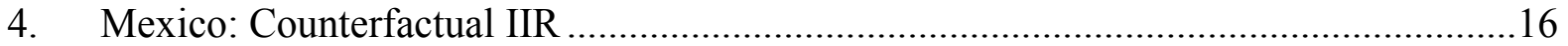




\section{INTRODUCTION}

Pension "privatization" (social security reform characterized by the introduction of a definedcontribution pension scheme) aims at correcting actuarial imbalances at the root of long-run solvency problems in pre-existing Pay-As-You-Go (PAYGO) defined-benefit public pension systems. However, other things equal, the reform's diversion of social security contributions to private personal accounts deprives the general government of revenues without an offsetting reduction in public spending because ongoing pension payments to existing pensioneers must continue, at least during a transition period. During this transition, governments often resort to market financing to make up for lost social security contribution revenue, leading to an increase in public debt.

During the wave of pension reform - particularly in Latin America during the 1990s - it was often argued that issuing debt to cover the imbalances that usually followed such reforms was not a cause for concern, since it just meant replacing implicit pension debt (IPD) with "explicit" public debt. A PAYGO system is an intergenerational redistribution mechanism based on the rollover of IPD across generations of workers. ${ }^{4}$ Contributors implicitly buy claims to future income from the government, which uses the proceeds to finance the benefits of retirees - that is, to redeem previously issued claims. But after pension privatization the government cannot rollover pension claims any further, and must find new financing for the redemption of pension claims falling due. Thus, financing the payments of benefits to pensioners (or making up for lost contribution revenue) by issuing financial debt would be, in some sense, gradually making IPD explicit. ${ }^{5}$ However, if markets do not consider IPD and explicit public debt as equivalent, then turning one into the other could affect the market's perception of a government's credit risk.

Several factors would seem to make financial debt a more problematic liability for the government than IPD. In most cases, IPD can in fact be seen a contingent liability, ${ }^{6}$ whereas explicit financial debt is a firm commitment. By definition, IPD is a very long-dated liability, payable in the country's own currency, and positively correlated with the tax base. In contrast, in most countries' financial debt has a shorter average maturity, is often denominated in foreign currency, and its burden generally bears little relation to the tax base - if it does not bear a negative correlation to it. Creditors hold financial debt on a voluntary basis, which gives rise to relatively high rollover risks, whereas social security contributions are mandatory. More fundamentally, governments can, and often do, change the terms of PAYGO pension schemes, thereby restructuring IPD, whereas the terms of financial debt cannot be unilaterally modified.

\footnotetext{
${ }^{4}$ See Conesa and Garriga (2005).

${ }^{5}$ Strictly speaking, making up for lost contribution revenue with financial borrowing is to replace a flow of new implicit financing with a flow of new explicit borrowing. Issuing "recognition bonds" to compensate workers for the loss of acquired rights, as has been done under some pension reforms, is closer to the idea of making the stock of IPD explicit, although it really involves putting a definitive value on IPD.

${ }^{6}$ Pension obligations under a PAYGO defined-benefit system would be contingent on the life of the pensioneer who holds the claim, but also subject to discretionary changes in the parameters of the pension system itself.
} 
Not only does pension privatization change the composition of the government's liabilities; it also changes the relationship between government and pension scheme's participants. Under a defined-benefit, PAYGO-financed scheme, workers and retirees hold junior claims on the government, while bondholders and other creditors hold more senior claims. In fact, experience shows that governments will try to reduce pension benefits or increase pension contributions under PAYGO plans before considering defaulting on financial debt. Workers and retirees are like equity holders, subject to residual risk. However, once pension privatization takes place, workers and pensioners become, through their pension funds, creditors on a par with other bondholders. The bonds held by pension fund managers (largely government bonds) are the same bonds held by other investors. Thus, a reform that kept the size of total obligations unchanged, but transformed IPD into explicit debt would increase the riskiness of the government's balance sheet and dilute the value of the financial claims already held by creditors.

Starting from an unsustainable PAYGO scheme, a pension reform will usually aim at curbing the growth in total government liabilities over time. Thus, a pension privatization can involve a trade-off between reducing total public (implicit plus financial) debt in the long run, but increasing the riskiness of the composition of liabilities in the short and medium term as financial debt replaces IPD, at least during the transition period of the reform. This is not an argument against pension reform; it is an argument in favor of accompanying pension reform with fiscal efforts to offset the tendency of the reform to increase riskiness associated with the higher path of financial debt.

In this paper, we explore whether these conclusions can be supported by showing that financial markets - and financial analysts in particular-judge IPD and financial public debt differently as they assess sovereign creditworthiness. Our empirical evidence suggests that this may be, in fact, the case. This diverging perception of financial analysts over both types of debt may be simply due to their understanding of the intrinsic differences between the two, (as mentioned above), but it could also reflect myopia by the financial analysts themselves, who may not fully appreciate the obligations represented by IPD — notably, such a myopic perception of IPD by the markets would constitute yet another difference between IPD and explicit debt.

Previous research in this area is scant, but the few available studies have mixed views on the equivalence between implicit and explicit liabilities. ${ }^{7}$ When assessing the private sector, Feldstein and Seligman (1981) and Moody's (1998) argue that unfunded pension liabilities of corporations do end up reflected in corporate share prices and credit ratings. However, when assessing the determinants of sovereign credit risk, results are less clear. For example, Fiess (2003) seemingly confirms the differential treatment of financial debt and IPD for the case of Mexico, by observing that the country's credit ratings remained broadly unchanged before and after the 1997 pension system reform, despite the fact that the reform's features generated, upon its approval, an immediate reduction of IPD. More generally, a widely held view among practitioners is that net present value estimates of IPD should not influence

\footnotetext{
${ }^{7}$ However, economists have increasingly emphasized the need to include the concept of IPD in the standard set of debt sustainability indicators (see Holzman, Palacios and Zviniene, 2004).
} 
sovereign credit risk ratings for two reasons: first, these estimates are highly sensitive to small changes in parameters and assumptions, as noted by Truglia (2002) and Pinheiro $(2004){ }^{8}$ and second, they do not account for possible future policy actions to improve the finances of defined-benefit pension systems. ${ }^{9}$

We regress indicators of sovereign creditworthiness on IPD and explicit public debt, controlling for the main determinants of debt sustainability. The analysis shows that crosscountry differences in financial public debt help explain differences in sovereign credit ratings, but differences in IPD do not. The apparent lack of attention to IPD on the assessment of sovereign creditworthiness could be an indication that markets, though concerned over contingent liabilities, simply do not trust available measures of IPD, which are subject to considerable error. To address this problem, we also estimate dynamic panel models of credit ratings that look at the effects of pension privatization without using direct measures of IPD. These models also suggest that markets focus mainly on explicit public debt levels without giving much weight to the IPD reductions generated by pension privatization. The corollary is that if a government wants to preserve its credit standing while it carries out a radical pension reform, then it must strengthen its non-pension fiscal balance to offset the loss of revenue from social security contributions, and avoid incurring additional explicit liabilities to finance the transition costs of the reform.

To illustrate the results of the econometric analysis, we present one simple counterfactual pension reform scenario. We look at the case of Mexico, which privatized its pension system in the late 1990's We construct simple fiscal scenario to show what might have happened to public debt and ratings, other things being equal, if it had done otherwise, and calculate the resulting impact on their credit standing, in line with our econometric estimates. This case helps illustrate the corollary mentioned above: public debt can become hard to manage when a country undertaking pension privatization does not offset its adverse cash flow effects with fiscal adjustment.

\section{Country Risk, Credit Ratings ANd Implicit Pension DebT (IPD)}

Financial debt is an important variable for rating agencies assessing government credit risk, and there is a strong relationship between a sovereign's debt and its credit rating (Figure 1). ${ }^{10}$ For instance, as Argentina's federal government debt rose from 341/2 percent of GDP in 1997 to about 135 percent of GDP in 2002, Standard and Poor's gradually downgraded its rating from BB to CC and ultimately SD (default). Similarly, Argentina's rating by the Institutional Investor's Country Credit Rating (IIR) System — which captures the aggregate views of

\footnotetext{
${ }^{8}$ In particular, Pinheiro (2004) argues that in the late nineties estimates of IPD for Brazil from various sources varied by as much as sixty percent of GDP.

${ }^{9}$ See Moody's Investor Service's Sovereign Risk Unit managing director Truglia (2002).

${ }^{10}$ General government debt is one key criterion for both Moody's and Standard and Poor's for assigning sovereign credit ratings, as stressed by Powell and Martinez (2008). Many other variables affect ratingsincluding the country's default history, the external and fiscal stance and the perceived institutional and governability status - which explains why advanced countries such as Japan, Belgium, Italy, Portugal and Spain can be in the "AA" range despite their high debts. These countries can rollover debt with relative ease, and there is no question on their ability to pay.
} 
economists and financial analysts on sovereign creditworthiness - fell from about $42 \frac{1}{2}$ in 1999 to $343 / 4$ in 2001 and $23 \% / 4$ by $2002 .{ }^{11}$

Credit ratings are closely correlated with the risk premia countries face in the international capital markets (Figure 2). Thus, markets seem to penalize the same developments that rating agencies consider harmful to a country's creditworthiness, and are certainly informed by the ratings themselves. In this context, an increase in explicit debt (even if it is related to a generally beneficial pension reform), could be perceived as a sign of deteriorating creditworthiness - and be reflected in worsening borrowing terms for the sovereign.

Figure 1. Standard and Poor's Credit Ratings and Government Debt

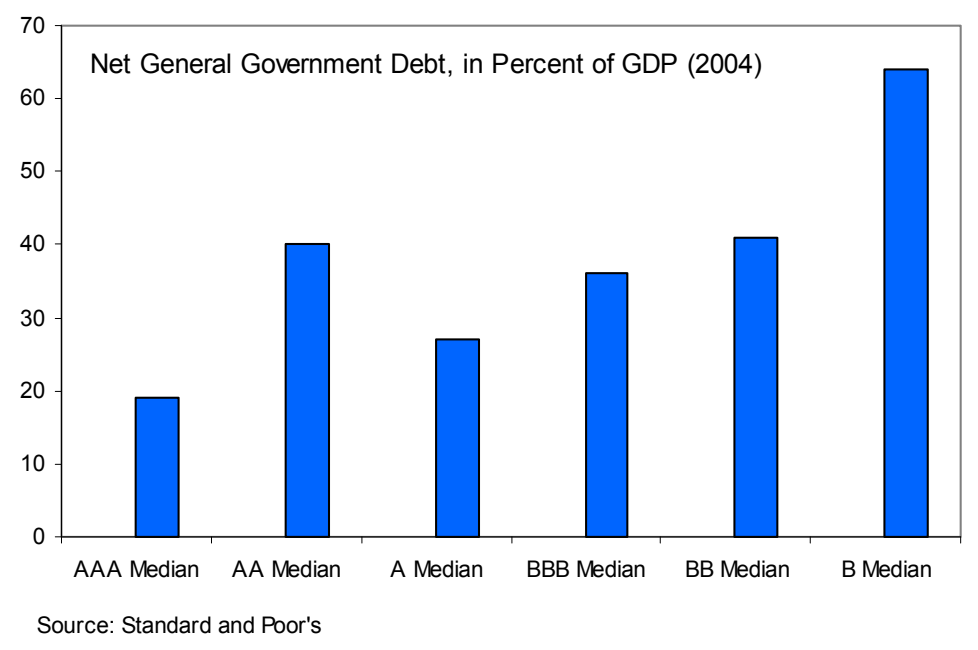

Figure 2. Risk Premia and International Investor Ratings

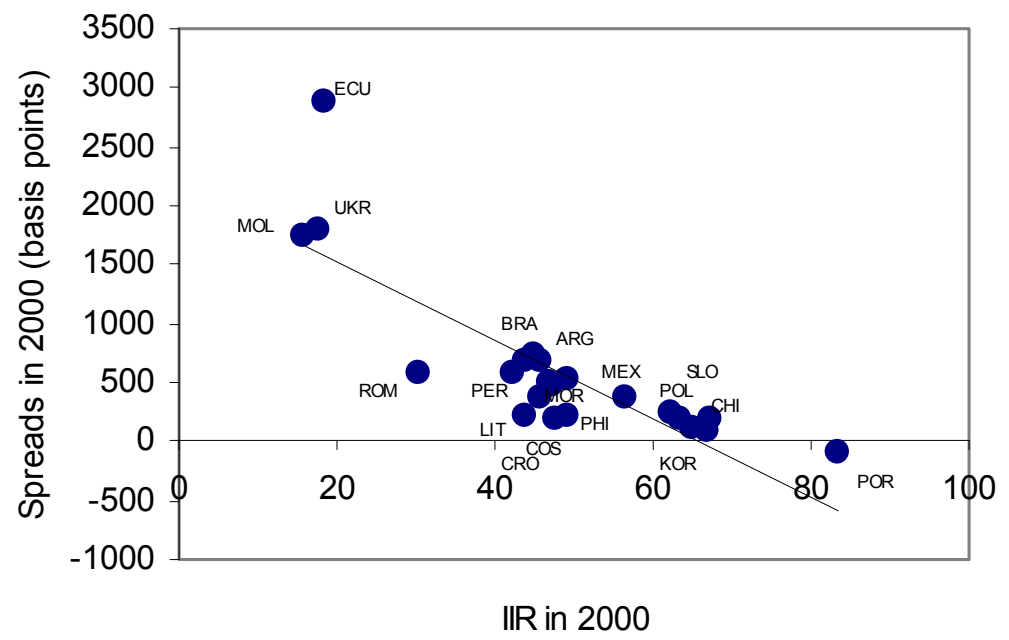

Sources: JP M organ and International Investor Ratings

\footnotetext{
${ }^{11}$ The country credit ratings developed by the Institutional Investor (IIR) are based on information provided by senior economists and sovereign-risk analysts at leading global banks and money management and securities firms. Respondents grade each country in a scale of 0 to 100 , where 100 represents the least chance of default.
} 
The close link between financial debt and country risk is well documented, as noted in Powell and Martinez (2008). Moreover, some aspects of such link have been summed up in the concepts of "original sin" and "debt intolerance". Eichengreen, Hausman and Panizza (2003, 2003a) define as the "original sin" a country's inability to borrow abroad in its own currency, even in the presence of good institutions and stability. In the context of pension reform, the "original sin" theory suggests that even if IPD is brought under control by the reform, the country may find it difficult to find financing on adequate terms for the transition costs arising from the reform itself. Reinhart, Rogoff and Savastano (2003) define "debt intolerance" as the inability of emerging countries to function with levels of external debt that are easily manageable for advanced countries. A corollary of this view in the context of pension reform is that financing the transition costs with debt can generate or raise instability. Reinhart et al. (2003) also show that, as debt increases, the ratings fall more rapidly in emerging countries than in advanced economies, a phenomenon that may be interpreted as a perception of lower debt management capacity in emerging markets.

In any case, whether IPD and explicit public debt are seen as equivalent by the financial markets is an empirical issue. In the following section we take this question to the data.

\section{ECONOMETRIC ANALYSIS}

To test the hypothesis that IPD matters as much as financial debt for credit risk assessments we first use a direct approach, based on cross-country regressions of IIR against IPD, controlling for financial public debt and other factors. ${ }^{12}$ This approach is constrained by data availability, especially since it is difficult to find data on IPD for a large sample of countries.

We also use an indirect approach based on the idea that if financial markets care about IPD, they should react positively to a pension privatization reform that reduces it. The coefficient of a pension reform dummy should capture the impact that reducing IPD has on the rating. This approach does not require estimates of IPD, which allows us to use a much larger sample of countries, and to avoid the measurement and conceptual problems affecting IPD estimates. Moreover, we can use panel regressions in this case, since we have identified 21 countries where a pension privatization took place and the ratings and control variables can be sampled over several years. The main constraint for this regression is the availability of time series for country ratings.

\section{Direct Approach}

As our dependent variable, we use a transformation of the IIR for 2000, defined as 100 minus the original IIR (thus, for our variable, a value of 100 represents the highest risk of default). That is, a positive sign in an estimated coefficient means that a variable has a positive effect on the perceived probability of default. The focus of the analysis is a measure of IPD in 33

\footnotetext{
${ }^{12}$ As noted by Baek, et al. (2005), in the country risk literature, indicators of sovereign creditworthiness are usually represented by ratings of agencies and publications. For example, Jacque el al. (1996) also use the IIR and the Economic Intelligence Unit (EIU), while Cantor and Packer (1996) use Moody's and S\&P ratings.
} 
countries in 1999/2000 taken from Holzman, Palacios and Zviniene (2004), which is the widest homogeneous IPD data set available. The well-known debt sustainability condition suggests that the primary balance in percent of GDP and real growth should be on the righthand side of a regression explaining the perceived creditworthiness of a sovereign, along with financial debt. Two measures of financial debt are used: in dataset (A), we include the public debt series as a share of GDP, presented in Holzman et al (2004), while dataset (B) uses the public debt series provided by Tsibouris et al (2006), to ensure robustness in our results regarding coverage..$^{13}$ In addition, international reserves, inflation, country size (proxied by the ratio of the country's GDP relative to that of the U.S.), the current account balance in percent of GDP, an index of political stability ${ }^{14}$ and an indicator of the regional "Original Sin" (as calculated by Hausmman and Panizza (2003) $)^{15}$ are used as control variables. All variables are for the year 2000, with the exception of real growth, which is the average for 1995-2000, and the "Original Sin", which is averaged for 1999-2001 (Annexes B and $\mathrm{C}$ ).

We test for the effect of debt and IPD on country ratings by defining two different model specifications. In the first case, debt and IPD enter into the regression linearly, and a single coefficient for their impact on IIR is estimated across the sampled countries. The second specification allows for country-specific effects on the coefficients for debt and IPD by rescaling these variables by each country's relative size to the US economy.

Our estimates suggest that rating agencies do not consider financial debt and IPD equivalent when assessing country risk (Table 1, columns 1, 3, 5 and 7). Public debt has the expected positive sign and is significant across specifications; in contrast, the coefficient on IPD is close to zero, and not significant in all specifications, including those allowing for nonlinearities on the countries' size. The coefficients on average growth rate, reserves, primary balance and relative size of the country are broadly significant across specifications and, as expected, tend to reduce the probability of default. The coefficient of the index of political stability has the expected sign, but is significant only in some of the specifications, suggesting that economic factors are the most important in the assessment of sovereign country risk. The multicollinearity test using the VIF (Variance Inflation Factor) reveals weak multicollinearity between total debt and the current account balance (Annex D). Thus, the same regressions are estimated by considering the net exports rather than the current account balance. The estimates for this specification are reported in columns 2, 4, 6 and 8 , and broadly similar in magnitude and level of significance to those that included the current account balance.

\footnotetext{
${ }^{13}$ The key difference in the series is that of coverage, with the Tsibouris et al. (2006) database including generally wider public sector debt in its series.

${ }^{14}$ The political stability variable measures the likelihood of violence threats to, or changes in, government, including terrorism. The source is Kaufmann, Kraay and Mastruzzi (2005) and it is measured in units ranging from -2.5 to 2.5 , with higher values corresponding to more stability.

${ }^{15}$ See "OSIN3" variable, Haussmann and Pannizza (2004), Table 1.
} 
Based on our regression estimates, we can reject the null hypothesis that the coefficients of IPD and public debt are equal. This provides support for the idea that markets see important differences between a sovereign's pension liabilities and financial public debt - differences which are relevant for the assessment of country risk. In consequence, making IPD explicit by financing the transition costs of a pension reform in the financial markets could trigger a deterioration of sovereign credit ratings.

Table 1. Institutional Investor Ratings (IIR), IPD and Debt.

\begin{tabular}{|c|c|c|c|c|c|c|c|c|}
\hline & \multicolumn{4}{|c|}{ (A) Holzman et al (2004) } & \multicolumn{4}{|c|}{ (B) Tsibouris et al (2006) } \\
\hline & \multicolumn{2}{|c|}{$\begin{array}{l}\text { Non-Interacted Debt } \\
\text { and IPD }\end{array}$} & \multicolumn{2}{|c|}{$\begin{array}{c}\text { Debt and IPD interacted } \\
\text { with Relative Country } \\
\text { Size }\end{array}$} & \multicolumn{2}{|c|}{$\begin{array}{c}\text { Non-Interacted Debt } \\
\text { and IPD }\end{array}$} & \multicolumn{2}{|c|}{$\begin{array}{c}\text { Debt and IPD interacted } \\
\text { with Relative Country } \\
\text { Size }\end{array}$} \\
\hline & 1 & 2 & 3 & 4 & 5 & 6 & 7 & 8 \\
\hline Constant & $\begin{array}{c}56.28 \\
(0.00)^{\star * *}\end{array}$ & $\begin{array}{c}56.67 \\
(0.00)^{\star * *}\end{array}$ & $\begin{array}{c}64.63 \\
(0.00)^{\star * \star}\end{array}$ & $\begin{array}{c}66.98 \\
(0.00)^{\star * *}\end{array}$ & $\begin{array}{c}59.61 \\
(0.00)^{\star * *}\end{array}$ & $\begin{array}{c}59.29 \\
(0.00)^{\star \star *}\end{array}$ & $\begin{array}{c}66.10 \\
(0.00)^{\star * \star}\end{array}$ & $\begin{array}{c}68.43 \\
(0.00)^{* * *}\end{array}$ \\
\hline Public Debt & $\begin{array}{c}13.13 \\
(0.08)^{*}\end{array}$ & $\begin{array}{c}14.56 \\
(0.05)^{\star *}\end{array}$ & $\begin{array}{c}-1,071.25 \\
(0.07)^{*}\end{array}$ & $\begin{array}{c}-982.69 \\
(0.11)\end{array}$ & $\begin{array}{c}13.71 \\
(0.02)^{\star *}\end{array}$ & $\begin{array}{c}14.01 \\
(0.01)^{\star \star *}\end{array}$ & $\begin{array}{c}-1,588.71 \\
(0.06)^{\star *}\end{array}$ & $\begin{array}{c}-1,535.34 \\
(0.10)^{*}\end{array}$ \\
\hline IPD & $\begin{array}{l}-0.10 \\
(0.95)\end{array}$ & $\begin{array}{c}0.08 \\
(0.96)\end{array}$ & $\begin{array}{l}28.43 \\
(0.49)\end{array}$ & $\begin{array}{l}28.27 \\
(0.51)\end{array}$ & $\begin{array}{l}-0.52 \\
(0.75)\end{array}$ & $\begin{array}{l}-0.48 \\
(0.76)\end{array}$ & $\begin{array}{l}119.57 \\
(0.17)\end{array}$ & $\begin{array}{l}119.84 \\
(0.21)\end{array}$ \\
\hline Primary Balance & $\begin{array}{l}-1.20 \\
(0.11)\end{array}$ & $\begin{array}{l}-1.25 \\
(0.11)\end{array}$ & $\begin{array}{l}-0.65 \\
(0.36)\end{array}$ & $\begin{array}{l}-0.75 \\
(0.35)\end{array}$ & $\begin{array}{l}-0.75 \\
(0.27)\end{array}$ & $\begin{array}{l}-0.74 \\
(0.28)\end{array}$ & $\begin{array}{l}-0.95 \\
(0.19)\end{array}$ & $\begin{array}{l}-1.00 \\
(0.20)\end{array}$ \\
\hline Reserves & $\begin{array}{c}-96.31 \\
(0.00)^{\star \star \star}\end{array}$ & $\begin{array}{l}-100.45 \\
(0.00)^{\star \star *}\end{array}$ & $\begin{array}{l}-68.92 \\
(0.01)^{\star \star \star}\end{array}$ & $\begin{array}{l}-70.15 \\
(0.02)^{\star \star}\end{array}$ & $\begin{array}{l}-85.99 \\
(0.01)^{\star \star \star}\end{array}$ & $\begin{array}{l}-85.69 \\
(0.01)^{\star \star \star}\end{array}$ & $\begin{array}{l}-77.51 \\
(0.00)^{\star \star \star}\end{array}$ & $\begin{array}{l}-78.52 \\
(0.01)^{\star \star \star}\end{array}$ \\
\hline Average Growth & $\begin{array}{l}-1.66 \\
(0.17)\end{array}$ & $\begin{array}{l}-1.83 \\
(0.15)\end{array}$ & $\begin{array}{l}-1.58 \\
(0.10)^{*}\end{array}$ & $\begin{array}{l}-1.79 \\
(0.11)\end{array}$ & $\begin{array}{l}-1.96 \\
(0.10)^{*}\end{array}$ & $\begin{array}{l}-1.94 \\
(0.09)^{*}\end{array}$ & $\begin{array}{l}-1.76 \\
(0.08)^{*}\end{array}$ & $\begin{array}{l}-1.95 \\
(0.09)^{*}\end{array}$ \\
\hline Inflation & $\begin{array}{c}-0.02 \\
(0.88)\end{array}$ & $\begin{array}{c}-0.03 \\
(0.83)\end{array}$ & $\begin{array}{c}0.12 \\
(0.29)\end{array}$ & $\begin{array}{c}0.13 \\
(0.29)\end{array}$ & $\begin{array}{c}0.08 \\
(0.47)\end{array}$ & $\begin{array}{c}0.08 \\
(0.52)\end{array}$ & $\begin{array}{c}0.10 \\
(0.40)\end{array}$ & $\begin{array}{c}0.10 \\
(0.40)\end{array}$ \\
\hline Current Account & $\begin{array}{l}-0.39 \\
(0.21)\end{array}$ & & $\begin{array}{l}-0.55 \\
(0.05)\end{array}$ & & $\begin{array}{l}-0.01 \\
(0.98)\end{array}$ & & $\begin{array}{l}-0.53 \\
(0.09)^{*}\end{array}$ & \\
\hline Net Exports & & $\begin{array}{l}-0.37 \\
(0.14)\end{array}$ & & $\begin{array}{l}-0.47 \\
(0.15)\end{array}$ & & $\begin{array}{c}0.02 \\
(0.96)\end{array}$ & & $\begin{array}{l}-0.46 \\
(0.15)\end{array}$ \\
\hline Relative GDP & $\begin{array}{l}-216.24 \\
(0.06)^{*}\end{array}$ & $\begin{array}{c}-194.88 \\
(0.11)\end{array}$ & & & $\begin{array}{l}-219.85 \\
(0.05)^{\star *}\end{array}$ & $\begin{array}{c}-221.78 \\
(0.06)^{*}\end{array}$ & & \\
\hline Political Stability & $\begin{array}{l}-7.48 \\
(0.14)\end{array}$ & $\begin{array}{l}-7.11 \\
(0.15)\end{array}$ & $\begin{array}{l}-10.34 \\
(0.06)^{*}\end{array}$ & $\begin{array}{l}-9.90 \\
(0.07)^{*}\end{array}$ & $\begin{array}{l}-6.62 \\
(0.19)\end{array}$ & $\begin{array}{l}-6.61 \\
(0.19)\end{array}$ & $\begin{array}{l}-10.86 \\
(0.05)^{\star *}\end{array}$ & $\begin{array}{l}-10.48 \\
(0.07)^{*}\end{array}$ \\
\hline Original Sin & $\begin{array}{l}17.09 \\
(0.29)\end{array}$ & $\begin{array}{l}16.26 \\
(0.36)\end{array}$ & $\begin{array}{c}8.92 \\
(0.57)\end{array}$ & $\begin{array}{c}6.62 \\
(0.71)\end{array}$ & $\begin{array}{l}12.36 \\
(0.43)\end{array}$ & $\begin{array}{l}12.47 \\
(0.44)\end{array}$ & $\begin{array}{l}10.44 \\
(0.48)\end{array}$ & $\begin{array}{c}8.12 \\
(0.63)\end{array}$ \\
\hline $\begin{array}{l}\text { Observations } \\
\text { R-squared }\end{array}$ & $\begin{array}{c}33 \\
0.72 \\
\end{array}$ & $\begin{array}{c}33 \\
0.72\end{array}$ & $\begin{array}{c}33 \\
0.69\end{array}$ & $\begin{array}{c}33 \\
0.68\end{array}$ & $\begin{array}{c}33 \\
0.74\end{array}$ & $\begin{array}{c}33 \\
0.74\end{array}$ & $\begin{array}{c}33 \\
0.70\end{array}$ & $\begin{array}{c}33 \\
0.69\end{array}$ \\
\hline
\end{tabular}




\section{Indirect Approach}

We assess the impact of enacting a pension reform law on credit ratings by estimating a panel regression with fixed effects, in which country risk is the dependent variable and the key regressor is a dummy variable indicating a pension reform. The panel used in this section contains data for 63 countries, including available data for each country between 1979 and 2003. The credit risk perception is again measured using the IIR. The dataset has 20 countries where a pension privatization reform took place in the period 1979-2003; introduction of a fully funded pension scheme is represented with dummy variables following three different specifications. ${ }^{16}$ In the first specification, the dummy takes a unit value the year the pension reform law is enacted. Taking the year of enactment as the date of the pension reform implies that the expectation of a known upcoming reduction in IPD should be immediately reflected in the country's rating if the rating agencies are concerned about IPD. In the second specification, the dummy variable equals one both in the year of the reform and on the years that follow, to capture the permanent effect that the reform might have on country ratings. The third specification has dummy variables for the short term after the reform (when the reform is $0-4$ years old), medium term (5-8 years old) and long term (9+ years old).

The control variables are largely as in the direct approach. The variables that represent macroeconomic and fiscal conditions are total public debt, international reserves, the primary balance, and the current account balance, all expressed in percent of GDP; real growth, inflation and country size (once more measured as the ratio of a country's GDP to that of the U.S.). Unfortunately, the political stability and Original Sin variables are not available for a sufficiently long period to be included in the exercise. ${ }^{17}$

We employ two different panel estimation techniques. We start with a static panel to estimate a model similar to the cross-country regressions in the direct approach. We also estimate a dynamic panel data analysis including instrumental variables for two reasons. First, the high persistence of IIR ratings might indicate a "reputation effect" (thus, the lagged ratings could contain relevant economic information); second, more robust estimation techniques can rule out potential inconsistency and biases in our regressions.

\section{Static Panel}

The estimates for our static panel regressions indicate that pension reform dummies (and hence, IPD) generally do not help explain a country's credit rating. Table 2 shows the results of the indirect approach following a model similar to the one used in the cross-country regressions. In general, the pension reform dummy variables are not significant ${ }^{18}-\mathrm{a}$

\footnotetext{
${ }^{16}$ The countries are Argentina, Bolivia, Chile, Colombia, Costa Rica, Ecuador, El Salvador, Mexico, Peru, Poland, Uruguay, Iceland, Kazakhstan, Latvia, Russia, Slovakia, Estonia, Lithuania, Bulgaria and Croatia.

${ }^{17}$ The Variance Inflation Factor (VIF) shows no multicollinearity among these variables (Annex E).

${ }^{18}$ The exception is the medium-term dummy variable in the third specification, both when included alone and when interacted by the country's relative size. This implies that the pension reform might improve the rating
} 
surprising result, given that about 80 percent of the pension reforms in the sample also cut workers' pension benefits, which should have reduced the probability of defaulting on total debt in the future, at least to some extent. Most control variables have the expected signs. Total debt has a positive and significant effect on the probability of default (as measured by the IIR), while international reserves reduce this probability. Inflation has a significant but low positive coefficient, but the current account has an unexpected sign. Country size and the primary balance have the expected negative sign, but the coefficients are not significant. These results suggest that given the relevance of total debt and international reserves in the country risk assessments, the rest of the macroeconomic variables might have a relatively minor bearing for the rating agencies.

\section{Dynamic Panel}

As noted earlier, data inspection ${ }^{19}$ suggests that our static panel results might be subject to potential problems of biased and inconsistent estimators. To address these issues, we estimate a dynamic panel using a two-stage least squares (2SLS) method yielding asymptotically efficient estimates of our coefficients,${ }^{20}$ including the first lag of the suspected endogenous variables as instruments in the regression (Table 3$).^{21}$

The estimation results are somewhat more mixed. In our first model, which considers both debt and the pension dummy variables independently of country size, the exercise again suggests that pension reform has not had a significant impact in the determination of credit ratings. In particular, the pension privatization dummy variables have statistically insignificant coefficients under each one of their potential specifications. Higher growth rates and primary balances reduce the probability of default as perceived by the rating agencies. Also, total debt and inflation raise perceived country risk. Most of the remaining control variables have the expected signs and are significant. ${ }^{22}$ On the other hand, allowing for the interaction between the countries' relative size with the debt and pension dummy variables delivers a coefficient for public financial debt with a significant but unexpected negative sign, possibly suggesting that the "quality" of the country - as measured by its relative economic power - might have relatively more bearing on the sovereign's IIR ranking than its actual debt stock. ${ }^{23}$ At the same time, pension dummies generally continue to prove insignificant and, at best, their effect on country ratings would seem to show with a considerable lag and fade away quickly.

only after 4 years. However, the lack of significance of the long-term dummy variable could mean that benefit on country ratings again fade away 8 years after the reform.

${ }^{19}$ The Arellano-Bond test confirms the existence of serial correlation of order one in our dataset.

${ }^{20}$ See Technical Appendix.

${ }^{21}$ The bottom of Table 3 displays the tests for serial correlation, and the number of observations and countries.

The tests for serial correlation show that there is no serial correlation of order 1 and 2 .

${ }^{22}$ The current account balance and international reserves have unexpected signs, as they appear to raise the perception of default.

${ }^{23}$ Furthermore, the relative size indicator could likely be picking up the impact of other structural issues (such as political stability and the "original sin" ranking) which were not available for the panel regressions under the indirect method. 
In sum, the econometric evidence suggests that, under a reasonable range of specifications and estimation methods, rating agencies treat IPD and financial public debt differently. As argued earlier, there are good reasons that could explain this differentiation, and this is a factor that must be taken into account when planning a pension reform.

Table 2. IIR and Pension Reform: Static Panel Estimation with Fixed Effects

\begin{tabular}{|c|c|c|c|c|c|c|}
\hline & \multicolumn{3}{|c|}{ Non-Interacted Debt and Dummies } & \multicolumn{3}{|c|}{$\begin{array}{c}\text { Debt and Pension Dummies interacted } \\
\text { with Relative Country Size }\end{array}$} \\
\hline & $\begin{array}{c}1 \\
\text { Pension } \\
\text { Temporal } \\
\text { Dummy }\end{array}$ & $\begin{array}{c}2 \\
\text { Pension } \\
\text { Permanent } \\
\text { Dummy }\end{array}$ & $\begin{array}{c}3 \\
\text { Pension } \\
\text { Dummy by } \\
\text { Period }\end{array}$ & $\begin{array}{c}4 \\
\text { Pension } \\
\text { Temporal } \\
\text { Dummy }\end{array}$ & $\begin{array}{c}5 \\
\text { Pension } \\
\text { Permanent } \\
\text { Dummy }\end{array}$ & $\begin{array}{c}6 \\
\text { Pension } \\
\text { Dummy by } \\
\text { Period }\end{array}$ \\
\hline Constant & $\begin{array}{c}46.73 \\
(0.00)^{\star * *}\end{array}$ & $\begin{array}{c}46.770 \\
(0.00)^{\star \star *}\end{array}$ & $\begin{array}{c}46.59 \\
(0.00)^{\star \star \star}\end{array}$ & $\begin{array}{c}47.614 \\
(0.00)^{\star \star *}\end{array}$ & $\begin{array}{c}47.51 \\
(0.00)^{* * *}\end{array}$ & $\begin{array}{c}47.48 \\
(0.00)^{* * *}\end{array}$ \\
\hline Total Debt & $\begin{array}{l}7.97 \\
(0.00)^{\star * *}\end{array}$ & $\begin{array}{c}7.76 \\
(0.00)^{\star * *}\end{array}$ & $\begin{array}{c}7.78 \\
(0.00)^{* * *}\end{array}$ & $\begin{array}{c}24.00 \\
(0.08)^{*}\end{array}$ & $\begin{array}{l}22.35 \\
(0.11)\end{array}$ & $\begin{array}{l}22.43 \\
(0.11)\end{array}$ \\
\hline Pension Temporal Dummy & $\begin{array}{c}0.91 \\
(0.44)\end{array}$ & & & $\begin{array}{l}64.77 \\
(0.11)\end{array}$ & & \\
\hline Pension Permanent Dummy & & $\begin{array}{l}-4.05 \\
(0.12)\end{array}$ & & & $\begin{array}{c}-106.79 \\
(0.21)\end{array}$ & \\
\hline Pension Dummy Short Run & & & $\begin{array}{l}-3.22 \\
(0.24)\end{array}$ & & & $\begin{array}{l}-39.82 \\
(0.70)\end{array}$ \\
\hline Pension Dummy Medium Run & & & $\begin{array}{c}-7.62 \\
(0.01)^{\star * *}\end{array}$ & & & $\begin{array}{l}-156.88 \\
(0.04)^{\star \star}\end{array}$ \\
\hline Pension Dummy Long Run & & & $\begin{array}{l}-5.19 \\
(0.13)\end{array}$ & & & $\begin{array}{c}-40.002 \\
(0.90)\end{array}$ \\
\hline Primary Balance & $\begin{array}{l}-2.62 \\
(0.83)\end{array}$ & $\begin{array}{l}-3.87 \\
(0.74)\end{array}$ & $\begin{array}{l}-5.27 \\
(0.66)\end{array}$ & $\begin{array}{c}6.09 \\
(0.64)\end{array}$ & $\begin{array}{c}4.78 \\
(0.72)\end{array}$ & $\begin{array}{c}4.65 \\
(0.72)\end{array}$ \\
\hline Reserves & $\begin{array}{c}-24.72 \\
(0.01)^{\star * *}\end{array}$ & $\begin{array}{c}-24.76 \\
(0.01)^{\star * *}\end{array}$ & $\begin{array}{c}-24.20 \\
(0.01)^{\star * *}\end{array}$ & $\begin{array}{c}-26.60 \\
(0.00)^{\star * *}\end{array}$ & $\begin{array}{c}-26.58 \\
(0.00)^{\star \star *}\end{array}$ & $\begin{array}{c}-26.49 \\
(0.00)^{\star * *}\end{array}$ \\
\hline Current Account Balance & $\begin{array}{c}21.53 \\
(0.01)^{\star * *}\end{array}$ & $\begin{array}{c}19.69 \\
(0.01)^{* *}\end{array}$ & $\begin{array}{c}19.05 \\
(0.01)^{* *}\end{array}$ & $\begin{array}{c}24.74 \\
(0.01)^{\star \star \star}\end{array}$ & $\begin{array}{c}23.50 \\
(0.01)^{\star * \star}\end{array}$ & $\begin{array}{c}23.27 \\
(0.01)^{\star * *}\end{array}$ \\
\hline Growth & $\begin{array}{c}0.03 \\
(0.79)\end{array}$ & $\begin{array}{c}0.03 \\
(0.70)\end{array}$ & $\begin{array}{c}0.02 \\
(0.79)\end{array}$ & $\begin{array}{l}0.047 \\
(0.62)\end{array}$ & $\begin{array}{l}-0.04 \\
(0.63)\end{array}$ & $\begin{array}{l}-0.05 \\
(0.61)\end{array}$ \\
\hline Inflation & $\begin{array}{c}0.00 \\
(0.00)^{\star * *}\end{array}$ & $\begin{array}{c}0.00 \\
(0.00)^{\star \star \star}\end{array}$ & $\begin{array}{c}0.00 \\
(0.00)^{\star \star \star *}\end{array}$ & $\begin{array}{c}0.00 \\
(0.07)^{*}\end{array}$ & $\begin{array}{c}0.00 \\
(0.06)^{*}\end{array}$ & $\begin{array}{c}0.00 \\
(0.05)^{*}\end{array}$ \\
\hline Relative GDP & $\begin{array}{c}-57.030 \\
(0.19)\end{array}$ & $\begin{array}{l}-55.24 \\
(0.19)\end{array}$ & $\begin{array}{l}-53.83 \\
(0.18)\end{array}$ & & & \\
\hline Observations & 831 & 831 & 831 & 831 & 831 & 831 \\
\hline R-squared & 0.41 & 0.41 & 0.42 & 0.32 & 0.33 & 0.33 \\
\hline Number of Countries & 63 & 63 & 63 & 63 & 63 & 63 \\
\hline
\end{tabular}


Table 3. IIR and Pension Reform: Dynamic Panel (2SLS) Estimation Results

\begin{tabular}{|c|c|c|c|c|c|c|}
\hline & \multicolumn{3}{|c|}{ Non-Interacted Debt and Dummies } & \multicolumn{3}{|c|}{$\begin{array}{c}\text { Debt and Pension Dummies interacted with } \\
\text { Relative Country Size }\end{array}$} \\
\hline & $\begin{array}{c}1 \\
\text { Temporal } \\
\text { Dummy } \\
\end{array}$ & $\begin{array}{c}2 \\
\text { Permanent } \\
\text { Dummy }\end{array}$ & $\begin{array}{c}3 \\
\text { Dummy by } \\
\text { Period }\end{array}$ & $\begin{array}{c}4 \\
\text { Temporal } \\
\text { Dummy } \\
\end{array}$ & $\begin{array}{c}5 \\
\text { Permanent } \\
\text { Dummy } \\
\end{array}$ & $\begin{array}{c}6 \\
\text { Dummy by } \\
\text { Period } \\
\end{array}$ \\
\hline Constant & $\begin{array}{l}-0.18 \\
(0.76)\end{array}$ & $\begin{array}{c}0.48 \\
(0.47)\end{array}$ & $\begin{array}{c}-4.23 \\
(0.00)^{\star * *}\end{array}$ & $\begin{array}{c}0.04 \\
(0.94)\end{array}$ & $\begin{array}{c}0.20 \\
(0.68)\end{array}$ & $\begin{array}{c}0.16 \\
(0.76)\end{array}$ \\
\hline Total Debt & $\begin{array}{l}1.54 \\
(0.13)\end{array}$ & $\begin{array}{l}1.49 \\
(0.14)\end{array}$ & $\begin{array}{c}1.26 \\
(0.10)^{*}\end{array}$ & $\begin{array}{l}-18.48 \\
(0.10)^{*}\end{array}$ & $\begin{array}{l}-18.51 \\
(0.09)^{*}\end{array}$ & $\begin{array}{l}-17.72 \\
(0.10)^{*}\end{array}$ \\
\hline Pension Temporal Dummy & $\begin{array}{l}-0.07 \\
(0.89)\end{array}$ & & & $\begin{array}{l}11.65 \\
(0.62)\end{array}$ & & \\
\hline Pension Permanent Dummy & & $\begin{array}{l}-0.81 \\
(0.36)\end{array}$ & & & $\begin{array}{l}-62.83 \\
(0.33)\end{array}$ & \\
\hline Pension Dummy Short Run & & & $\begin{array}{l}-0.81 \\
(0.36)\end{array}$ & & & $\begin{array}{l}-21.88 \\
(0.59)\end{array}$ \\
\hline Pension Dummy Medium Run & & & $\begin{array}{l}-1.14 \\
(0.20)\end{array}$ & & & $\begin{array}{l}-60.41 \\
(0.06)^{*}\end{array}$ \\
\hline Pension Dummy Long Run & & & $\begin{array}{c}0.92 \\
(0.62)\end{array}$ & & & $\begin{array}{c}80.00 \\
(0.05)^{\star *}\end{array}$ \\
\hline Primary Balance & $\begin{array}{l}-2.26 \\
(0.54)\end{array}$ & $\begin{array}{l}-2.14 \\
(0.56)\end{array}$ & $\begin{array}{l}-2.26 \\
(0.54)\end{array}$ & $\begin{array}{l}-1.98 \\
(0.60)\end{array}$ & $\begin{array}{l}-1.91 \\
(0.61)\end{array}$ & $\begin{array}{l}-2.01 \\
(0.59)\end{array}$ \\
\hline Reserves & $\begin{array}{c}4.290 \\
\left(0.064^{*}\right.\end{array}$ & $\begin{array}{c}4.18 \\
(0.07)^{\star}\end{array}$ & $\begin{array}{c}4.01 \\
(0.09)^{\star}\end{array}$ & $\begin{array}{c}4.61 \\
(0.07)^{*}\end{array}$ & $\begin{array}{c}4.45 \\
(0.08)^{*}\end{array}$ & $\begin{array}{c}4.34 \\
(0.10)\end{array}$ \\
\hline Current Account Balance & $\begin{array}{c}11.15 \\
(0.00)^{* * \star}\end{array}$ & $\begin{array}{c}10.81 \\
(0.00)^{\star * *}\end{array}$ & $\begin{array}{c}10.49 \\
(0.00)^{* \star *}\end{array}$ & $\begin{array}{c}10.95 \\
(0.01)^{\star * *}\end{array}$ & $\begin{array}{c}10.37 \\
(0.01)^{\star * *}\end{array}$ & $\begin{array}{c}9.73 \\
(0.01)^{\star \star \star}\end{array}$ \\
\hline Growth & $\begin{array}{l}-0.06 \\
(0.04)^{\star *}\end{array}$ & $\begin{array}{l}-0.06 \\
(0.04)^{\star \star}\end{array}$ & $\begin{array}{l}-0.06 \\
(0.04)^{\star *}\end{array}$ & $\begin{array}{l}-0.07 \\
(0.03)^{\star \star}\end{array}$ & $\begin{array}{l}-0.07 \\
(0.02)^{\star \star}\end{array}$ & $\begin{array}{l}-0.06 \\
(0.05)^{\star \star}\end{array}$ \\
\hline Inflation & $\begin{array}{c}0.00 \\
(0.00)^{\star * \star}\end{array}$ & $\begin{array}{c}0.00 \\
(0.00)^{\star \star \star}\end{array}$ & $\begin{array}{l}0.00 \\
(0.00)^{\star * \star}\end{array}$ & $\begin{array}{c}0.00 \\
(0.00)^{\star * \star}\end{array}$ & $\begin{array}{c}0.00 \\
(0.00)^{\star * \star}\end{array}$ & $\begin{array}{c}0.00 \\
(0.00)^{\star \star \star}\end{array}$ \\
\hline Relative GDP & $\begin{array}{l}-22.03 \\
(0.36)\end{array}$ & $\begin{array}{l}-21.39 \\
(0.37)\end{array}$ & $\begin{array}{c}-20.52 \\
(0.37)\end{array}$ & & & \\
\hline L. IIR & $\begin{array}{c}0.37 \\
(0.00)^{\star * \star}\end{array}$ & $\begin{array}{c}0.36 \\
(0.00)^{\star \star *}\end{array}$ & $\begin{array}{c}0.35 \\
(0.00)^{* \star *}\end{array}$ & $\begin{array}{c}0.39 \\
(0.00)^{* * *}\end{array}$ & $\begin{array}{c}0.40 \\
(0.00)^{* * *}\end{array}$ & $\begin{array}{c}0.39 \\
(0.00)^{\star \star *}\end{array}$ \\
\hline $\begin{array}{l}\text { L. Total Debt } \\
\text { L. Total Debt *Relative GDP }\end{array}$ & $\begin{array}{c}1.80 \\
(0.01)^{\star \star}\end{array}$ & $\begin{array}{c}1.77 \\
(0.01)^{\star *}\end{array}$ & $\begin{array}{c}1.72 \\
(0.02)^{\star \star}\end{array}$ & $\begin{array}{l}11.98 \\
(0.23)\end{array}$ & $\begin{array}{l}11.20 \\
(0.23)\end{array}$ & $\begin{array}{l}10.52 \\
(0.27)\end{array}$ \\
\hline L. Pension Temporal Dummy & $\begin{array}{c}0.01 \\
(0.98)\end{array}$ & & & $\begin{array}{c}3.24 \\
(0.88)\end{array}$ & & \\
\hline L. Pension Permanent Dummy & & $\begin{array}{l}-0.60 \\
(0.20)\end{array}$ & & & $\begin{array}{c}-38.72 \\
(0.00)^{\star * *}\end{array}$ & \\
\hline L. Pension Dummy Short Run & & & $\begin{array}{c}0.51 \\
(0.24)\end{array}$ & & & $\begin{array}{l}-53.48 \\
(0.02)^{\star \star}\end{array}$ \\
\hline L. Pension Dummy Medium Run & & & $\begin{array}{l}-1.67 \\
(0.03)^{* *}\end{array}$ & & & $\begin{array}{c}-92.27 \\
(0.00)^{\star \star \star}\end{array}$ \\
\hline L. Pension Dummy Long Run & & & $\begin{array}{c}2.68 \\
(0.29)\end{array}$ & & & $\begin{array}{c}320.68 \\
(0.00)^{\star \star \star}\end{array}$ \\
\hline L. Primary Balance & $\begin{array}{c}-8.36 \\
(0.07)^{\star}\end{array}$ & $\begin{array}{c}-8.41 \\
(0.07)^{*}\end{array}$ & $\begin{array}{l}-8.290 \\
(0.07)^{*}\end{array}$ & $\begin{array}{c}-9.36 \\
(0.06)^{\star}\end{array}$ & $\begin{array}{c}-9.29 \\
(0.07)^{*}\end{array}$ & $\begin{array}{c}-8.91 \\
(0.08)^{*}\end{array}$ \\
\hline L. Reserves & $\begin{array}{l}-2.70 \\
(0.51)\end{array}$ & $\begin{array}{l}-2.90 \\
(0.47)\end{array}$ & $\begin{array}{l}-2.47 \\
(0.53)\end{array}$ & $\begin{array}{l}-3.60 \\
(0.40)\end{array}$ & $\begin{array}{l}-3.36 \\
(0.41)\end{array}$ & $\begin{array}{l}-2.87 \\
(0.47)\end{array}$ \\
\hline L. Current Account Balance & $\begin{array}{c}9.59 \\
(0.01)^{\star * \star}\end{array}$ & $\begin{array}{c}9.54 \\
(0.01)^{\star \star \star}\end{array}$ & $\begin{array}{c}9.35 \\
(0.01)^{\star \star \star}\end{array}$ & $\begin{array}{c}8.99 \\
(0.01)^{\star \star \star}\end{array}$ & $\begin{array}{c}8.87 \\
(0.02)^{\star *}\end{array}$ & $\begin{array}{c}8.68 \\
(0.02)^{\star \star}\end{array}$ \\
\hline L. Growth & $\begin{array}{c}-0.09 \\
(0.00)^{* * *}\end{array}$ & $\begin{array}{c}-0.090 \\
(0.00)^{* \star *}\end{array}$ & $\begin{array}{c}-0.09 \\
(0.00)^{\star * *}\end{array}$ & $\begin{array}{c}-0.10 \\
(0.00)^{\star * *}\end{array}$ & $\begin{array}{c}-0.10 \\
(0.00)^{\star \star *}\end{array}$ & $\begin{array}{c}-0.10 \\
(0.00)^{\star \star \star}\end{array}$ \\
\hline L. Inflation & $\begin{array}{c}0.00 \\
(0.00)^{\star \star *}\end{array}$ & $\begin{array}{c}0.00 \\
(0.00)^{\star \star \star}\end{array}$ & $\begin{array}{c}0.00 \\
(0.00)^{\star \star \star}\end{array}$ & $\begin{array}{c}0.00 \\
(0.01)^{\star \star *}\end{array}$ & $\begin{array}{c}0.00 \\
(0.01)^{\star \star \star}\end{array}$ & $\begin{array}{c}0.00 \\
(0.01)^{\star \star \star}\end{array}$ \\
\hline L. Relative GDP & $\begin{array}{l}-7.49 \\
(0.43)\end{array}$ & $\begin{array}{l}-7.84 \\
(0.43)\end{array}$ & $\begin{array}{l}-8.13 \\
(0.41)\end{array}$ & & & \\
\hline$\overline{\mathrm{m} 1}$ & 1.26 & 1.23 & 1.40 & 1.34 & 1.16 & 1.28 \\
\hline $\mathrm{m} 2$ & -1.33 & -1.30 & -1.14 & -1.15 & -1.27 & 0.99 \\
\hline Observations & 651 & 651 & 651 & 651 & 651 & 651 \\
\hline R-squared & 0.57 & 0.57 & 0.58 & 0.55 & 0.56 & 0.58 \\
\hline Number of Countries & 60 & 60 & 60 & 60 & 60 & 60 \\
\hline
\end{tabular}




\section{A Counterfactual Study: Mexico’s Pension Reform}

In this section we illustrate the implications of pension reform by constructing simple counterfactual scenarios for the Mexican case As the country undertook a radical pension reforms in the nineties, we ask how fiscal balances and debt would have evolved if such a reform had not taken place. For this purpose, we construct a counterfactual scenario by adding to fiscal revenues the contributions actually paid into individual capitalization accounts by the insured populations since the reform. We also reduce the government interest bill in proportion to the debt that the government would have avoided issuing if they had received those contributions as revenue. We keep the observed underlying (non-pension) fiscal balance. The construction of such a counterfactual helps illustrate the order of magnitude of the adjustment needed in the fiscal sector if a pension reform is to be absorbed without allowing the trajectory of financial debt to change.

\section{A. Pension Privation in Mexico}

The Mexican pension reform replaced the old defined-benefit, PAYGO system for private sector workers with a privately managed, defined-contributions scheme in July 1997. According to Zviniene and Packard (2002), this reform reduced IPD by 7 percent of GDP by 2001. With the reform, workers affiliated to the old program had to switch to the new one. These workers (but not those joining social security schemes for the first time after the reform) retained the option of retiring under the provisions of the old scheme by transferring to the government the assets accumulated in their capitalization accounts at the moment of retiring. Thus, while the government remained liable to service its previous implicit contracts when workers chose to remain under the old scheme, it stopped collecting the pension contributions paid by all private sector workers.

As noted earlier, Fiess (2003) examined country risk indexes for Mexico before and after the pension reform, concluding that it had no impact on country risk. While we agree with this observation, we argue that the pension reform did not have a negative impact on the country's credit rating because the government made a significant effort to control its total explicit debt - which, as we have seen, is the main indicator used by rating agencies in determining their risk assessments. ${ }^{24}$

To illustrate this point, we calculate a counterfactual scenario for Mexico's public debt as explained earlier. ${ }^{25} \mathrm{We}$ add to fiscal revenues workers' contributions to their private capitalization accounts (AFORES) and subtract from government expenditures the interest

\footnotetext{
${ }^{24}$ Another possibility (see Gil, Packard and Yermo (2005), chapter 3) is that the negligible effect on Mexico's country risk may reflect the country's low IPDs by Latin American standards prior to the reform. However, even if relatively low by regional standards, IPD was high in absolute terms and the reform reduced it by a significant amount in a few years.

${ }^{25}$ The concept of public debt used in the calculations shown in this section is the broadest one available for Mexico, the historical stock of the financial requirements of the public sector.
} 
cost that the government would have saved if it had reduced financing with those contributions (Figure 3). The contributions that actually went to private capitalization accounts represent the gap between the actual primary balance and the counterfactual primary balance; both measures show a surplus between 1996 and 2004. The exercise reveals an effort to undo the easing of policies that followed the 1995 crisis. The path of the counterfactual debt following the pension reform in 1997 shows a clear downward trend, hinting that an adjustment of the non-pension or underlying balance prevented the large cash imbalance in the residual public pension system from causing financial debt to rise and thereby helped preserve the country's credit rating.

Figure 3. Mexico: Counterfactual Explicit Debt and Primary Balance

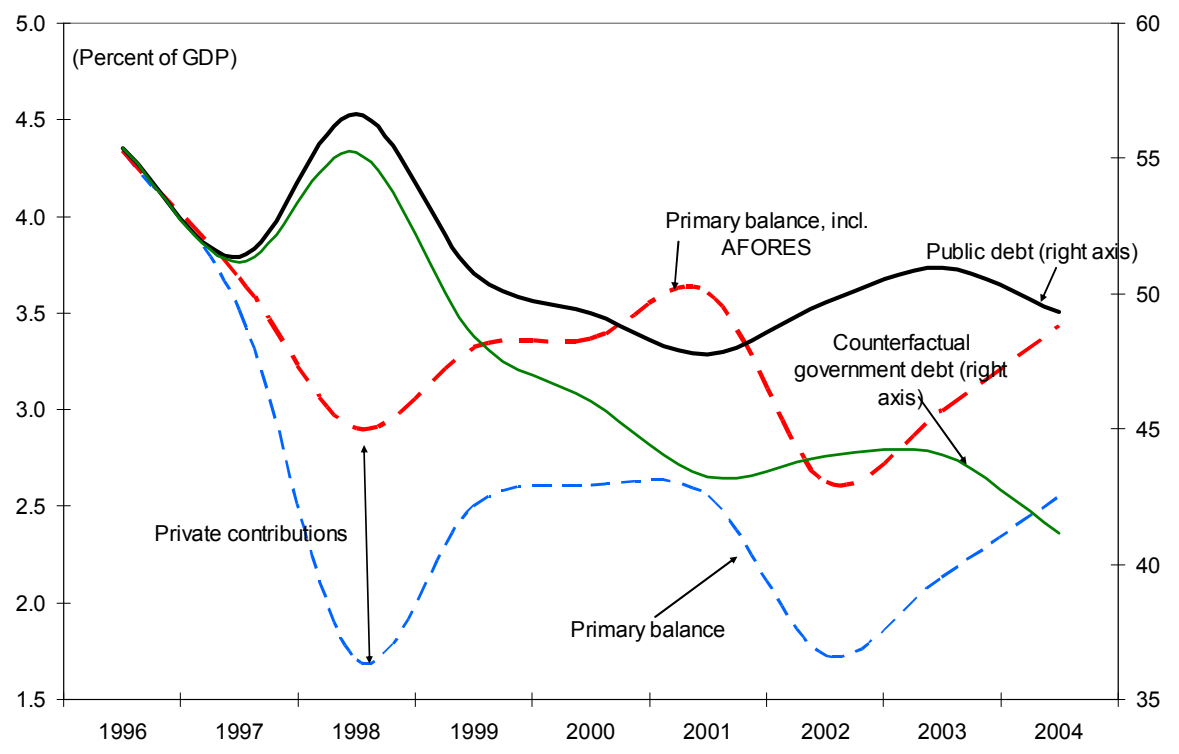

\section{B. Risk Assessment}

Based on the regression estimates of previous section, we measure the impact of pension reform on the Mexican credit rating. ${ }^{26}$ Table 4 summarizes the cumulative estimated effect of the pension reform on IPD and explicit debt in the country. By 2001, IPD had declined as expected, while explicit debt had risen moderately. In fact, the reduction in IPD exceeded, in absolute terms, the increase in financial debt, as one should have hoped for reforms aimed at improving long-term solvency. The final column presents the estimated impact of this change in Mexico's composition of public liabilities on the country's sovereign credit ratings, based on our estimates from Table 1 and the counterfactual debt scenario. In fact, the estimated sovereign credit risk was expected to rise marginally, given the limited increase in explicit

\footnotetext{
${ }^{26}$ The IIR used in this exercise is the one officially released, rather than the transformed variable used in the regressions presented in the previous sections.
} 
public debt, and despite the large reduction in IPD. This result is consistent with the observations presented by Fiess (2003).

Table 4. Estimated Impact of Pension Reform on IIR

\begin{tabular}{|c|c|c|c|c|}
\hline \multirow[t]{2}{*}{ Country } & \multirow[t]{2}{*}{$\begin{array}{l}\text { Pension reform } \\
\text { implementation }\end{array}$} & $\begin{array}{c}\text { Change in } \\
\text { Explicit Debt due } \\
\text { to the reform, } \\
2001\end{array}$ & $\begin{array}{c}\text { Reduction in IPD } \\
\text { due to the } \\
\text { reform, } 2001^{\mathrm{a}}\end{array}$ & \multirow[t]{2}{*}{$\begin{array}{c}\text { Estimated } \\
\text { change in IIR due } \\
\text { to the reform by } \\
2001^{\mathrm{b}} \\
\end{array}$} \\
\hline & & \multicolumn{2}{|c|}{ In percent of GDP } & \\
\hline Mexico & Jul-97 & 4.6 & 7.1 & 0.66 \\
\hline
\end{tabular}

a Source: Zviniene and Packard (2002) and authors.

${ }^{\mathrm{b}}$ Impact from the increase in explicit debt and the law enactment. Calculated from estimates presented in Table 1, specification A(2), and the counterfactual debt scenarios.

We also simulate the counterfactual credit ratings for Mexico over a time period (Figure 4), based on the estimation results of the dynamic panel estimates with a period dummy presented in Table 3 . The counterfactual rating comes from the difference between actual and counterfactual debt. ${ }^{27}$ According to our estimates, the IIR for Mexico in 2001 would have been 5.70 points better in the absence of a pension privatization - a relatively small amount, also in line with the results of Fiess (2003).

Figure 4. Mexico: Counterfactual IIR

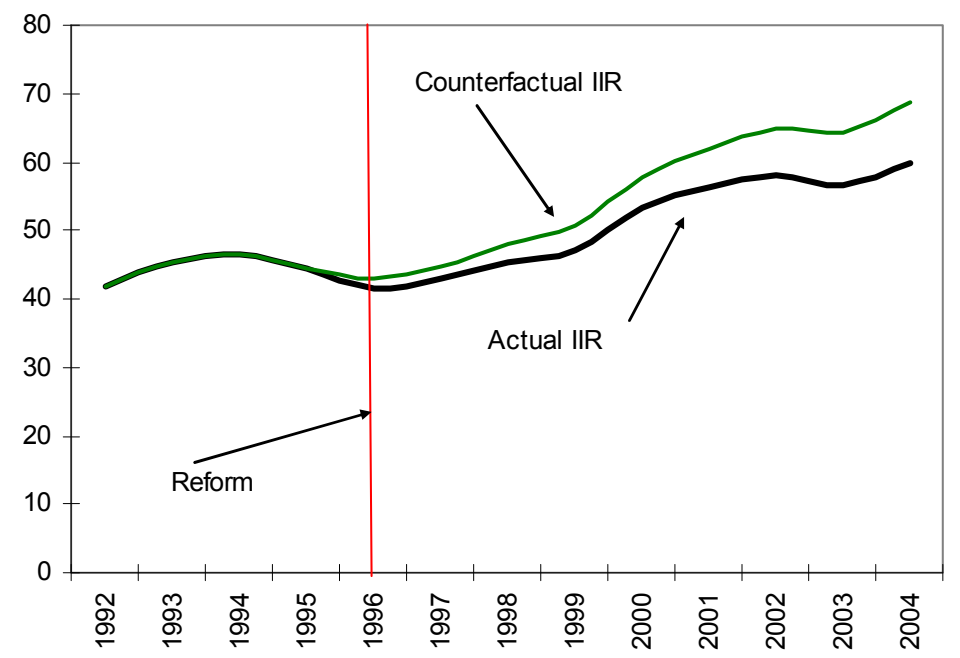

\footnotetext{
${ }^{27}$ The effect of the counerfactual primary balance is not taken into account into the counterfactual ratings, since the estimated coefficient on the primary balance is not statistically significant.
} 


\section{Conclusion}

In this paper, we explored the effect of a pension reform on country risk perceptions by examining the relevance of government debt and IPD debt for the credit ratings. We find that, rating agencies do not take into account IPD when assessing sovereign risk, but focus on the country's explicit financial debt. Now, determining whether this is the result of a rational assessment of the differences between IPD and financial debt - which we judge economically significant - or of myopia is probably besides the point. This bias (if we can call it so) in the assessment of sovereign risk appears to be robust to a reasonable range of model specifications, and does not just reflect problems in the measurement of IPD. Thus, the implications for the perception of creditworthiness of financing the transition costs of pension reform with debt, and a government's ability to finance them with adjustment, are factors to take into account when considering reform. It would be an error to waive the issue away by declaring that the reform simply makes implicit debt explicit.

A clear policy implication of the paper is that a radical pension reform that aims at improving a sovereign's long-term solvency by reducing implicit pension liabilities could end up increasing the riskiness of the government's balance sheet in the short and medium term, thereby hurting the country's credit rating, unless fiscal adjustment keeps the explicit debt trajectory from deteriorating. There are two corollaries to this conclusion. The first is that pension reforms require fiscal space to be implemented, to help compensate their transition costs in the short and medium terms. In support of pension privatization, the reforming government would be well advised to take policy actions to offset some or all of the transitional costs of the reform and their effects on the path of financial debt. The second is that when governments do not have room to implement the needed fiscal adjustment to offset the near- and medium-term cash costs of a pension privatization, it might be preferable to follow a gradual but decisive parametric approach to improve the sustainability to the PAYGO pension system before a transition to a fully-funded system might be undertaken. 


\section{AnNeXes}

\section{Annex A}

\begin{tabular}{|c|c|c|c|c|c|c|}
\hline \multicolumn{7}{|c|}{ Distribution of countries by rating, S\&P's 2004} \\
\hline AAA & AA & $A$ & BBB & BB & $\mathrm{B}$ & $\mathrm{CCC}$ \\
\hline Australia & Andorra & The Bahamas & Barbados & Brazil & Belize & Cameroon Dominican Republic \\
\hline Austria & Belgium & Bahrain & Bulgaria & Colombia & Benin & Ecuador \\
\hline Canada & Bermuda & Botswana & China & Cock Islands & Bolivia & \\
\hline Denmark & Italy & Chile & Croatia & Costa Rica & Burkina Faso & \\
\hline Finland & Japan & Cyprus & Kazakhstan & Egypt & Ghana & \\
\hline France & New Zeland & Czech Republic & Mexico & El Salvador & Grenada & \\
\hline Germany & Portugal & Estonia & Montserrat & Guatemala & Indonesia & \\
\hline Ireland & Spain & Greece & Oman & India & Jamaica & \\
\hline Isle of Man & Taiwan & Hong Kong & Poland & Jordan & Lebanon & \\
\hline Liechtenstein & & Hungary & Slovak Republic & Macedonia & Madagascar & \\
\hline Luxembourg & & Iceland & South Africa & Panama & Mali & \\
\hline Netherlands & & Israel & Thailand & Peru & Mongolia & \\
\hline Norway & & Korea & Trinidad and Tobago & Philipines & Mozambique & \\
\hline Singapore & & Kuwait & Tunisia & Romania & Pakistan & \\
\hline Sweden & & Latvia & & Russia & Jadua New Guinea & \\
\hline Switzerland & & Lithuania & & Turkey & Paraguay & \\
\hline United Kingdom & & Malaysia & & Vietnam & Senegal & \\
\hline United States & & Malta & & & Serbia & \\
\hline & & Qatar & & & Suriname & \\
\hline & & Saudi Arabia & & & Ukraine & \\
\hline & & Slovenia & & & Uriguay & \\
\hline & & & & & Venezuela & \\
\hline
\end{tabular}

Annex B

\begin{tabular}{|c|c|c|}
\hline Series & Description and sources & Sample period \\
\hline $\begin{array}{l}\text { Institutional Investor's Country } \\
\text { Credit Ratings }\end{array}$ & Institutional Investor & $1979-2003$ \\
\hline $\begin{array}{l}\text { Standard and Poor's Country } \\
\text { Sovereign Ratings }\end{array}$ & Standard and Poor's. & 2000 \\
\hline Implicit Pension Debt/GDP & $\begin{array}{l}\text { Holzmann, Palacios and Zviniene(2004), World } \\
\text { Bank Discussion papers }\end{array}$ & 2000 \\
\hline Political Stability & $\begin{array}{l}\text { World Bank's Governance Research Indicator } \\
\text { Country Snapshot (GRICS). }\end{array}$ & 2000 \\
\hline Public Debt/GDP & $\begin{array}{l}\text { Holzmann, Palacios and Zviniene(2004), World } \\
\text { Bank Discussion papers }\end{array}$ & $1979-2003$ \\
\hline Total Debt/GDP & $\begin{array}{l}\text { Experience with Large Fiscal Adjustments database: } \\
\text { Tsibouris et al. (2006). Completed with IMF data. }\end{array}$ & $1979-2003$ \\
\hline Primary Balance/GDP & $\begin{array}{l}\text { Experience with Large Fiscal Adjustments database: } \\
\text { Tsibouris et al. (2006) and OECD. }\end{array}$ & $1979-2003$ \\
\hline Reserves & World Development Indicators, World Bank. & 1979-2002 \\
\hline Growth Rate & World Development Indicators, World Bank. & $1979-2003$ \\
\hline Inflation & World Development Indicators, World Bank. & $1979-2003$ \\
\hline GDP & World Development Indicators, World Bank. & $1979-2003$ \\
\hline Current Account Balance & World Development Indicators, World Bank. & $1979-2003$ \\
\hline Net Exports & World Development Indicators, World Bank. & $1979-2003$ \\
\hline Pension Reform Dummy & Own Research & Different years \\
\hline Spreads & JP Morgan & 1998-2001 \\
\hline
\end{tabular}


Annex C

\begin{tabular}{ccc}
\hline Argentina & Hungary & Peru \\
Bolivia & Iran & Phillipines \\
Brazil & Korez & Poland \\
Chile & Kyrgyz Rep & Portugal \\
Colombia & Lithuania & Romania \\
Costa Rica & Malta & Senegal \\
Croatia & Mauritius & Slovakia \\
Dominican Rep & Mexico & Slovenia \\
Ecuador & Moldova & Turkey \\
El Salvador & Morocco & Ukraine \\
Estonia & Nicaragua & Uruguay \\
\hline
\end{tabular}

Annex D

\begin{tabular}{|c|c|c|}
\hline \multicolumn{3}{|c|}{ Variance Inflation } \\
\hline Variable & Factor $\left(\right.$ VIF $\left.^{\mathrm{a}}\right)$ & Tolerance $^{\mathrm{b}}$ \\
\hline CA Balance & 2.67 & 0.37 \\
\hline Total Debt & 2.52 & 0.40 \\
\hline Political Stability & 2.09 & 0.48 \\
\hline Inflation & 1.78 & 0.56 \\
\hline IPD & 1.69 & 0.59 \\
\hline Avg. Growth & 1.57 & 0.64 \\
\hline Reserves & 1.54 & 0.65 \\
\hline Primary Balance & 1.50 & 0.67 \\
\hline Relative GDP & 1.33 & 0.75 \\
\hline \multicolumn{3}{|c|}{ Variance Inflation } \\
\hline Variable & Factor $\left(\mathrm{VIF}^{\mathrm{a}}\right)$ & Tolerance $^{\mathrm{b}}$ \\
\hline Net Exports & 2.44 & 0.41 \\
\hline Political Stability & 2.07 & 0.48 \\
\hline Total Debt & 2.05 & 0.49 \\
\hline Inflation & 1.79 & 0.56 \\
\hline Avg. Growth & 1.71 & 0.58 \\
\hline IPD & 1.61 & 0.62 \\
\hline Reserves & 1.58 & 0.63 \\
\hline Primary Balance & 1.53 & 0.65 \\
\hline Relative GDP & 1.38 & 0.72 \\
\hline
\end{tabular}

${ }^{\mathrm{a}} \mathrm{VIF}=1 /\left(1-\mathrm{R}^{2}\right) ;{ }^{\mathrm{b}}$ Tolerance $=1-\mathrm{R}^{2}$ 
Annex E

\begin{tabular}{lcc}
\hline & $\begin{array}{c}\text { Variance Inflation } \\
\text { Factor }\left(\mathrm{VIF}^{\mathrm{a}}\right)\end{array}$ & Tolerance $^{\mathrm{b}}$ \\
\hline Pension Reform & 1.01 & 0.99 \\
Primary Balance & 1.13 & 0.88 \\
Total Debt & 1.11 & 0.90 \\
Reserves & 1.23 & 0.81 \\
Net Exports & 1.27 & 0.79 \\
Growth & 1.06 & 0.95 \\
Inflation & 1.01 & 0.99 \\
Relative GDP & 1.07 & 0.93 \\
\hline${ }^{\mathrm{a}} \mathrm{VIF}=1 /\left(1-\mathrm{R}^{2}\right) ;{ }^{\mathrm{b}}$ Tolerance=1-R &
\end{tabular}

Annex F

\begin{tabular}{|c|c|c|}
\hline & OLS & FE \\
\hline \multicolumn{3}{|l|}{ Institutional Investor Rating } \\
\hline L.iirating & $\begin{array}{c}1.00 \\
(0.00)^{* * *}\end{array}$ & $\begin{array}{c}0.92 \\
(0.00)^{\star * *}\end{array}$ \\
\hline \multicolumn{3}{|l|}{ Primary Balance } \\
\hline$\overline{L . p b}$ & $\begin{array}{c}0.80 \\
(0.00)^{\star \star *}\end{array}$ & $\begin{array}{c}0.67 \\
(0.00)^{\star * \star}\end{array}$ \\
\hline \multicolumn{3}{|l|}{ Inflation } \\
\hline L.inflation & $\begin{array}{c}0.30 \\
(0.12)\end{array}$ & $\begin{array}{r}0.22 \\
(0.03)^{\star *}\end{array}$ \\
\hline \multicolumn{3}{|l|}{ Growth } \\
\hline L.growth & $\begin{array}{c}0.61 \\
(0.00)^{\star \star \star} \\
\end{array}$ & $\begin{array}{c}0.36 \\
(0.00)^{\star \star \star} \\
\end{array}$ \\
\hline \multicolumn{3}{|l|}{ Current Account Balance } \\
\hline L.cabalance & $\begin{array}{c}0.79 \\
(0.00)^{\star * *}\end{array}$ & $\begin{array}{c}0.65 \\
(0.00)^{\star * *} \\
\end{array}$ \\
\hline \multicolumn{3}{|l|}{ Reserves } \\
\hline L.reserves & $\begin{array}{c}1.01 \\
(0.00)^{\star * *}\end{array}$ & $\begin{array}{c}0.88 \\
(0.00)^{\star * *}\end{array}$ \\
\hline \multicolumn{3}{|l|}{ Total Debt } \\
\hline L.totaldebt & $\begin{array}{c}0.99 \\
(0.00)^{\star * \star}\end{array}$ & $\begin{array}{c}0.82 \\
(0.00)^{\star * \star}\end{array}$ \\
\hline
\end{tabular}

Robust $p$ values in parentheses.

* significant at 10\%; ${ }^{* *}$ significant at $5 \%$; ${ }^{* * *}$ significant at $1 \%$ $\mathrm{L}$. indicates that the variable is lagged a period.

Year dummies included in all models. 


\section{TeChnical AppendiX}

There are two reasons for considering a dynamic panel data analysis for our estimation in section II. First, the high persistence of the ratings provided by the IIR might indicate a "reputation effect" faced by the rating agencies. Thus the lagged ratings should contain relevant economic information. The AR(1) process estimations for each dependent variable, included in Annex F, show that series such as the investor rating, current account balance, reserves and the total debt are highly persistent. Second, the size of the coefficients on total debt and international reserves estimated in the static panel seem very high, hinting at a possible overestimation.

The model considered here is:

$$
\begin{aligned}
& y_{i, t}=\beta x_{i, t}+\eta_{i}+v_{i, t} \\
& v_{i, t}=\rho v_{i, t-1}+\varepsilon_{i, t} \\
& \text { for } i=1, \ldots, N \text { and } t=2, \ldots, T, \\
& \text { where } \\
& E\left(\varepsilon_{i, s} \varepsilon_{i, t}\right)=0 \text { for } \mathrm{s} \neq t \\
& E\left(y_{i, t} \varepsilon_{i, t}\right)=0 \text { for } \mathrm{t}=2, \ldots, T
\end{aligned}
$$

The dependent variable, $\mathrm{y}_{\mathrm{i}, \mathrm{t}}$, represents the IIR for country $\mathrm{i}$ at period $\mathrm{t}$, while $\mathrm{x}_{\mathrm{i}, \mathrm{t}}$ represents a matrix containing the rest of the variables. There is an unobservable individual effect for each country, $\eta_{i}$. The error term is given by $v_{i, t}$. The Arellano-Bond test for serial correlation confirms the existence of serial correlation of order one for our dataset. In order to quantify the level of serial correlation the residuals from the ordinary least squares (OLS) estimation are regressed on the lagged residuals. This is

$$
\mathrm{v}_{\mathrm{i}, \mathrm{t}}=\rho \mathrm{v}_{\mathrm{i}, \mathrm{t}-1}+\varepsilon_{\mathrm{i}, \mathrm{t}} .
$$

Obtaining a significant and strong serial correlation of order one, represented by $\rho>0$. The static model is transformed in order to obtain a dynamic representation with serially uncorrelated shocks. Lagging equation 1 by one period and multiplying it by $\rho$ gives

$$
\rho y_{i, t-1}=\rho \beta x_{i, t-1}+\rho \eta_{i}+\rho v_{i, t-1}
$$

Using (3), equation (1) can be rewritten as

$$
\begin{aligned}
& y_{i, t}-\rho y_{i, t-1}=\beta x_{i, t}-\rho \beta x_{i, t-1}+\eta_{i}-\rho \eta_{i}+v_{i, t}-\rho v_{i, t-1} \\
& y_{i, t}=\rho y_{i, t-1}+\beta x_{i, t}-\rho \beta x_{i, t-1}+(1-\rho) \eta_{i}+\varepsilon_{i, t}
\end{aligned}
$$

This is a dynamic panel model with serially uncorrelated shocks.

Some considerations about estimation alternatives are relevant to find the consistent estimator for $\rho$ and $\beta$. Since the explanatory variable $y_{i, t-1}$ is positively correlated with the 
error term $(1-\rho) \eta_{i}+\varepsilon_{i, t}$ due to the presence of the individual effects, the OLS estimator in the levels equation (4) is inconsistent. This estimator is biased upwards as a result of the positive correlation between $\mathrm{y}_{\mathrm{i}, \mathrm{t}-1}$ and $\eta_{\mathrm{i}}$. In principle, the Fixed Effects $(\mathrm{FE})$ estimator could be seen as addressing this inconsistency by transforming equation (4) to eliminate $\eta_{i}$. This transformation consists in expressing the original observations as deviations from the individual means. OLS is used to estimate the transformed equation. The individual effects are removed from the transformed equations since the mean of the time invariant $\eta_{i}$ is itself $\eta_{\mathrm{i}}$. For simplicity, we focus on the simple AR(1) model, abstracting from the variables $\mathrm{y}_{\mathrm{i}, \mathrm{t}-2}$, $\mathrm{x}_{\mathrm{i}, \mathrm{t}}$ and $\mathrm{x}_{\mathrm{i}, \mathrm{t}-1}$, however, the same reasoning applies when they are present. The transformed model is given by

where

$$
\tilde{y}_{i, t}=\rho_{1} \tilde{y}_{i, t-1}+\tilde{\mathrm{e}}_{\mathrm{i}, \mathrm{t}}
$$

$$
\begin{gathered}
\tilde{y}_{i, t-1}=y_{i, t-1}-1 /(T-1)\left(y_{i, 1}+\ldots+y_{i, t}+\ldots+y_{i, T-1}\right) \\
\tilde{e}_{i, t}=e_{i, t}-1 /(T-1)\left(e_{i, 2}+\ldots+e_{i, t-1}+\ldots+e_{i, T}\right)
\end{gathered}
$$

Thus, this transformation implies a correlation between the transformed lagged dependent variable and the transformed error term. The component $-\mathrm{y}_{\mathrm{i}, \mathrm{t}} /(\mathrm{T}-1)$ in equation $(6)$ is correlated with $\mathrm{e}_{\mathrm{i}, \mathrm{t}}$ in equation (7), and the component $-\mathrm{e}_{\mathrm{i}, \mathrm{t}-\mathrm{l}} /(\mathrm{T}-1)$ in $(7)$ is correlated with $\mathrm{y}_{\mathrm{i}, \mathrm{t}-1}$ in (6). Nickel (1981) and Bond (2002) show that these negative correlations dominate positive correlations between other components such as $-\mathrm{e}_{\mathrm{i}, \mathrm{t}-1} /(\mathrm{T}-1)$ and $-\mathrm{y}_{\mathrm{i}, \mathrm{t}-\mathrm{1}} /(\mathrm{T}-1)$, so that the correlations between the transformed lagged dependent variable and the transformed error term are negative. This indicates that the FE estimator is biased downwards. Thus, we might expect that a consistent estimator will lie between OLS and FE estimates, or at least not be significantly out of the interval described by these two estimators.

A class of consistent estimators would require to first transforming the model to eliminate the individual effects and then apply instrumental variables. As noted before the FE estimator is not useful in this context, since it introduces the shocks from all time periods into the transformed error term. In this context, the first-differencing transformation has proved to be more promising. First differencing equation (4) gives

$$
\begin{aligned}
& \mathrm{y}_{\mathrm{i}, \mathrm{t}}-\mathrm{y}_{\mathrm{i}, \mathrm{t}-1}=\rho\left(\mathrm{y}_{\mathrm{i}, \mathrm{t}-1}-\mathrm{y}_{\mathrm{i}, \mathrm{t}-2}\right)+\beta\left(\mathrm{x}_{\mathrm{i}, \mathrm{t}}-\mathrm{x}_{\mathrm{i}, \mathrm{t}-1}\right)-\rho \beta\left(\mathrm{x}_{\mathrm{i}, \mathrm{t}-1}-\mathrm{x}_{\mathrm{i}, \mathrm{t}-2}\right)+\varepsilon_{\mathrm{i}, \mathrm{t}}-\varepsilon_{\mathrm{i}, \mathrm{t}-1} \\
& \Delta \mathrm{y}_{\mathrm{i}, \mathrm{t}}=\pi_{1} \Delta \mathrm{y}_{\mathrm{i}, \mathrm{t}-1}+\pi_{2} \Delta \mathrm{x}_{\mathrm{i}, \mathrm{t}}-\pi_{3} \Delta \mathrm{x}_{\mathrm{i}, \mathrm{t}-1}+\Delta \varepsilon_{\mathrm{i}, \mathrm{t}}
\end{aligned}
$$

For $\mathrm{t}=2, \ldots, \mathrm{T}$, for which we have the moment conditions:

$$
\begin{aligned}
& \mathrm{E}\left(\mathrm{y}_{\mathrm{i}, \mathrm{t}-\mathrm{s}} \Delta \varepsilon_{\mathrm{i}, \mathrm{t}}\right)=0 \text { for } \mathrm{s} \geq 2 \\
& \mathrm{E}\left(\mathrm{x}_{\mathrm{i}, \mathrm{t}-\mathrm{s}} \Delta \varepsilon_{\mathrm{i}, \mathrm{t}}\right)=0 \text { for } \mathrm{s} \geq 1
\end{aligned}
$$

In equation (8) the correlation between $\Delta \mathrm{y}_{\mathrm{i}, \mathrm{t}-1}$ and $\Delta \varepsilon_{\mathrm{i}, \mathrm{t}}$ is negative since $\Delta \mathrm{y}_{\mathrm{i}, \mathrm{t}-\mathrm{l}}=\mathrm{y}_{\mathrm{i}, \mathrm{t}-1}-\mathrm{y}_{\mathrm{i}, \mathrm{t}-2}$ and $\Delta \varepsilon_{\mathrm{i}, \mathrm{t}}=\varepsilon_{\mathrm{i}, \mathrm{t}}-\varepsilon_{\mathrm{i}, \mathrm{t}-1}$. However, if $\mathrm{y}_{\mathrm{i}, \mathrm{t}-1}$ is uncorrelated with the subsequent disturbances, $\varepsilon_{\mathrm{i}, \mathrm{t}}$, then $\mathrm{y}_{\mathrm{i}, \mathrm{t}-2}$ and $\Delta \mathrm{y}_{\mathrm{i}, \mathrm{t}-2}$ are valid instrumental variables for $\Delta \mathrm{y}_{\mathrm{i}, \mathrm{t}-1}$ in the first-differencing equations. The two-stage least squares (2SLS) estimator ${ }^{28}$ provides asymptotically efficient estimators in

${ }^{28}$ Also known as Anderson and Hsiao (1981) estimator. 
this context. In particular, for the small size that characterizes our sample. In the case of large samples the Generalized Method of Moments (GMM), developed by Hansen (1982) provides efficient estimators. 


\section{REFERENCES}

Anderson, T. W. and C. Hsiao (1981), Estimation of Dynamic Models with Error Components, Journal of the American Statistical Association, 76, 598-606.

Baek, In-Mee, A. Bandopadhyaya and Ch. Du (2005), "Determinants of market-assessed sovereign risk: Economic fundamentals or market appetite?", Journal of International Money and Finance, 24, 533-548.

Cantor, R., and F. Packer (1996), "Determinants and impact of sovereign credit ratings", Federal Reserve Bank of New York, Economic Policy Review 2(2), 37-53.

Conesa, J. C. and C. Garriga (2005), Optimal Design of Social Security Reforms. CREB working paper

Eichengreen, B. Hausman, R. and U. Panizza (2003), "The Pain of Original Sin" in Eichengreen, B. and R. Hausman (eds.), Debt Denomination and Financial Instability in Emerging-Market Economies, Chicago: University Press (forthcoming).

Eichengreen, B. Hausman, R. and U. Panizza (2003a), “Currency Mismatches, Debt Intolerance and Original Sin: Why they are not the same and why it matters", NBER working paper 10036.

Euwals, R. (2000), Do Mandatory Savings Decrease Household Savings? Evidence for the Netherlands, IZA Discussion Paper No. 113.

Feldstein and Seligman (1981), "Pension Funding, Share Prices and National Saving", Journal of Finance 36 (4) 801-24.

Fiess, N. (2003), "Pension Reform or Pension Default? A Note on Pension Reform and Country Risk", World Bank.

Gill, I., T. Packard, and J. Yermo (2005) Keeping the Promise Of Social Security in Latin America, Washington DC, The World Bank, 341 p.

Gustman, A.L., T. L. Steinmeier (1998), Effects of Pensions on Savings: Analysis with data from the Health and Retirement Study, NBER Working Paper 6681.

Haque, N. Kumar, M., Mark, N., and D. Mathieson (1996), "The economic content of indicators of developing country creditworthiness", IMF Staff Papers 43(4).

Hansen, L. P. (1982), Large Sample Properties of Generalized Method of Moments Estimators, Econometrica, 50, 1029-1054. 
Holzman, R., Palacios, R. and Zviniene, A. (2004), "Implicit Pension Debt: Issues, Measurement and Scope in International perspective", World Bank Social Protection Discussion Paper Series.

Kaufmann, Daniel Aart Kraay and Massimo Mastruzzi (2005). "Governance Matters IV: Governance Indicators for 1996-2004". Draft, May 2005

Krugman, P. (2005), “The Iceberg Cometh”, The New York Times.

Moody’s Investor Service (1998), “Moody’s Approach to analyzing pension obligations of corporations", Moody's Investor Service.

Pinheiro, V. (2004), "The Political Economy of Pension Reform in Brazil: A Historical Perspective", Inter-American Development Bank Working Paper.

Powell, A. and J. F. Martinez (2008), “On Emerging Economy Sovereign Spreads and Ratings”, IADB, Research Department, Working Paper No. 629.

Reinhart, C. Rogoff, K. and M. Savastano (2003), “Debt Intolerance”, NBER Working paper 9908.

Truglia, V. (2002), "Sovereign Ratings and Aging Societies", Paper presented at Rosenberg Institute of Global Finance Conference on "Financing Global Aging”, October 2002 www.brandeis.edu/global/rosenberg_papers/truglia_paper.pdf

Tsibouris, George C., Horton, M., Flanagan, M. and W. Maliszewski (2006), "Experience with Large Fiscal Adjustments", IMF Occasional Paper No. 246.

Zviniene, A. and T. Packard (2002), "A Simulation of Social Security Reforms in Latin America: What Has Been Gained”, Background Paper for Regional Study on Social Security Reform, The World Bank. 